\title{
First report of Livoneca guianensis (Isopoda: Cymothoidae) in Leporinus fasciatus (Pisces: Anostomidae) in Brazil
}

\author{
Primeiro registro de Livoneca guianensis (Isopoda: Cymothoidae) em Leporinus \\ fasciatus (Pisces: Anostomidae) no Brasil \\ Marcos Sidney Brito Oliveira1* (D); Marcos Tavares-Dias ${ }^{1,2}$ (D)
}

${ }^{1}$ Programa de Pós-graduação em Biodiversidade Tropical - PPGBio, Universidade Federal do Amapá - UNIFAP, Macapá, AP, Brasi ${ }^{2}$ Embrapa Amapá, Macapá, AP, Brasil

How to cite: Oliveira MSB, Tavares-Dias M. First report of Livoneca guianensis (Isopoda: Cymothoidae) in Leporinus fasciatus (Pisces: Anostomidae) in Brazil. Braz J Vet Parasito/ 2020; 29(4): e020420. https://doi.org/10.1590/S1984-29612020106

\begin{abstract}
This study aimed to report the first record of the occurrence of the parasite Livoneca guianensis in Leporinus fasciatus in Brazil. In September 2019, during surveys of the parasites in 12 specimens of $L$. fasciatus from the lower Jari River basin, in Amapá State, Brazil, one specimen of L. guianensis was found in the tongue of one host. The prevalence of $L$. guianensis was $8.3 \%$, and it was observed that this parasite has a geographic distribution restricted to South America, parasitizing fish species from Guyana and Brazil. This study contributed to the first report on the occurrence of $L$. guianensis for $L$. fasciatus in Brazil. In addition, increased the knowledge on the geographic distribution of this parasite with morphometric data, which are scarce for this Cymothoidae.
\end{abstract}

Keywords: Isopoda, ectoparasite, gill, freshwater fish, Jari River.

\section{Resumo}

Este estudo objetivou registrar a primeira ocorrência de Livoneca guianensis em Leporinus fasciatus no Brasil. Em setembro de 2019, durante uma pesquisa sobre parasitos em 12 espécimes de L. fasciatus do baixo Rio Jari, Estado do Amapá, norte do Brasil, um espécime de L. guianensis foi encontrado na língua de um hospedeiro. A prevalência de L. guianensis foi de 8,3\% e foi observado que esse parasito tem distribuição geográfica restrita à América do Sul, parasitando espécies de peixes da Guiana e do Brasil. Este estudo contribuiu com o primeiro relato da ocorrência de L. guianensis para L. fasciatus no Brasil. Além disso, aumentou o conhecimento sobre a distribuição geográfica desse parasito, contribuindo com dados morfométricos que são escassos para esse Cymothoidae.

Palavras-chave: Isopoda, ectoparasitos, brânquia, peixe de água doce, Rio Jari. 
Isopoda of the family Cymothoidae Leach, 1818 are obligatory ectoparasites with direct life cycle and they parasitize both marine and freshwater fish (Smit et al., 2014; Tavares-Dias et al., 2015; Oliveira et al., 2017). The genus Livoneca Leach, 1818 is consisted of 18 species of ectoparasites: Livoneca bowmani Brusca, 1981; Livoneca ovalis Say, 1818; Livoneca redmanii Leach, 1818; Livoneca desterroensis Thatcher, Souza-Conceição \& Jost de 2003; Livoneca enigmatica Fryer, 1968; Livoneca galinae Kononenko, 1989; Livoneca guianensis Van Name, 1925; Livoneca intermedia Nierstrasz, 1931; Livoneca lazzari Pearse, 1921; Livoneca orinoco Bowman \& Diaz-Ungria, 1957; Livoneca papernea Trilles, Colorni \& Golani, 1999; Livoneca parasilura Shen, 1933; Livoneca pomatoi Gaillat Airoldi, 1940; Livoneca reniformis Menzies \& Frankenberg, 1966; Livoneca ricinoides Risso, 1816; Livoneca soudanensis Richardson, 1911; Livoneca tenuistylis Richardson, 1912 and Livoneca texana Pearse, 1952 (Boyko et al., 2008). Livoneca guianensis was described only from the oral cavity of the fish Leporinus fasciatus Bloch, 1794 (Anostomidae) and Pimelodus clarias (Pimelodidae) from Guyana (Van Name, 1925). Thus, the present study contributes with the first report of L. guianensis for L. fasciatus in Brazil, in addition to providing morphometric data for this parasite, which are scarce.

In September 2019, 12 specimens of L. fasciatus were collected in the lower Jari River system [1 ${ }^{\circ} 9^{\prime} 6.23^{\prime \prime} S$ $51^{\circ} 59^{\prime 25.94 " W]}$, near the Jarilândia District, municipality of Vitória do Jari, Amapá State, Northern Brazil (Figure 1). Fish were collected using gillnets (15 m long, 1.5 deep, 20, 25 and $30 \mathrm{~mm}$ between knots) and were measured for total length $(\mathrm{cm})$ and weight $(\mathrm{g})$. All fish were examined for crustacean ectoparasites, which were maintained in ethanol solution (70\%) for $24 \mathrm{~h}$, and then preserved in alcohol (70\%) with glycerin (10\%) for further morphological analyses. Measurements recorded for the L. guianensis were the length and width of the body; length of the pereons, dactyls and pleonites; as well as length and width of the telson. The host and parasite were identified at the higher taxonomic level according to specialized literature (Van Name, 1925; Queiroz et al., 2013).

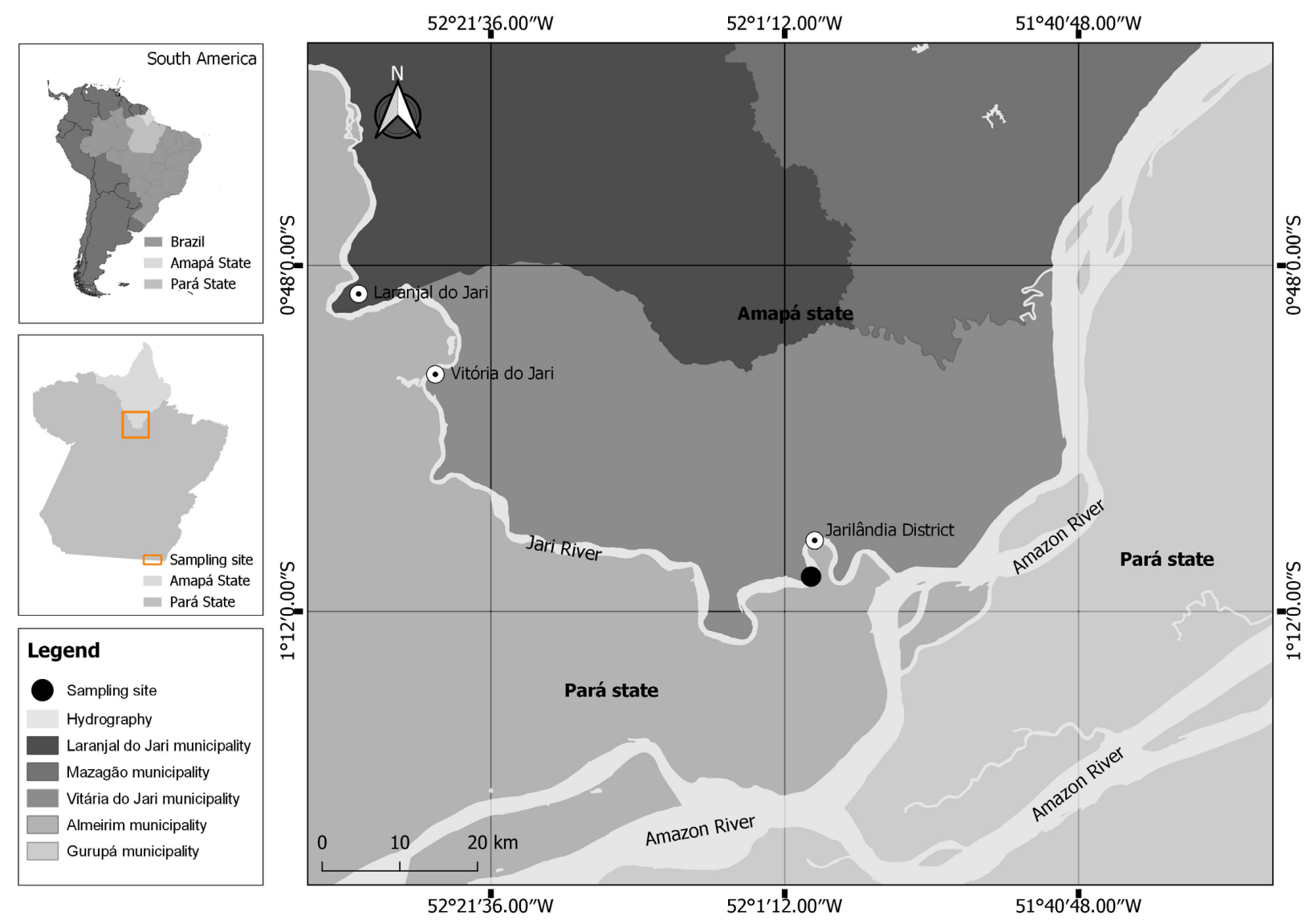

Figure 1. Collection site of Leporinus fasciatus in the Jari River basin, in eastern Amazon (Brazil).

Specimens of $L$. fasciatus (Figure 2A, B) showed an average media length of $18.1(10.8-26.2) \mathrm{cm}$ and average weight of 83.6 (11.8-183.8) g. Only one specimen (8.3\%) of $L$. fasciatus measuring $22.2 \mathrm{~cm}$ in length and weighing $111.2 \mathrm{~g}$ was parasitized by L. guianensis 9 (Figure 2C-F) that was found in the tongue of this host (Figure 2B). Small lesions were observed on the host tongue due to the fixation of the parasite claws. The measurements of L. guianensis are shown in Table 1. 

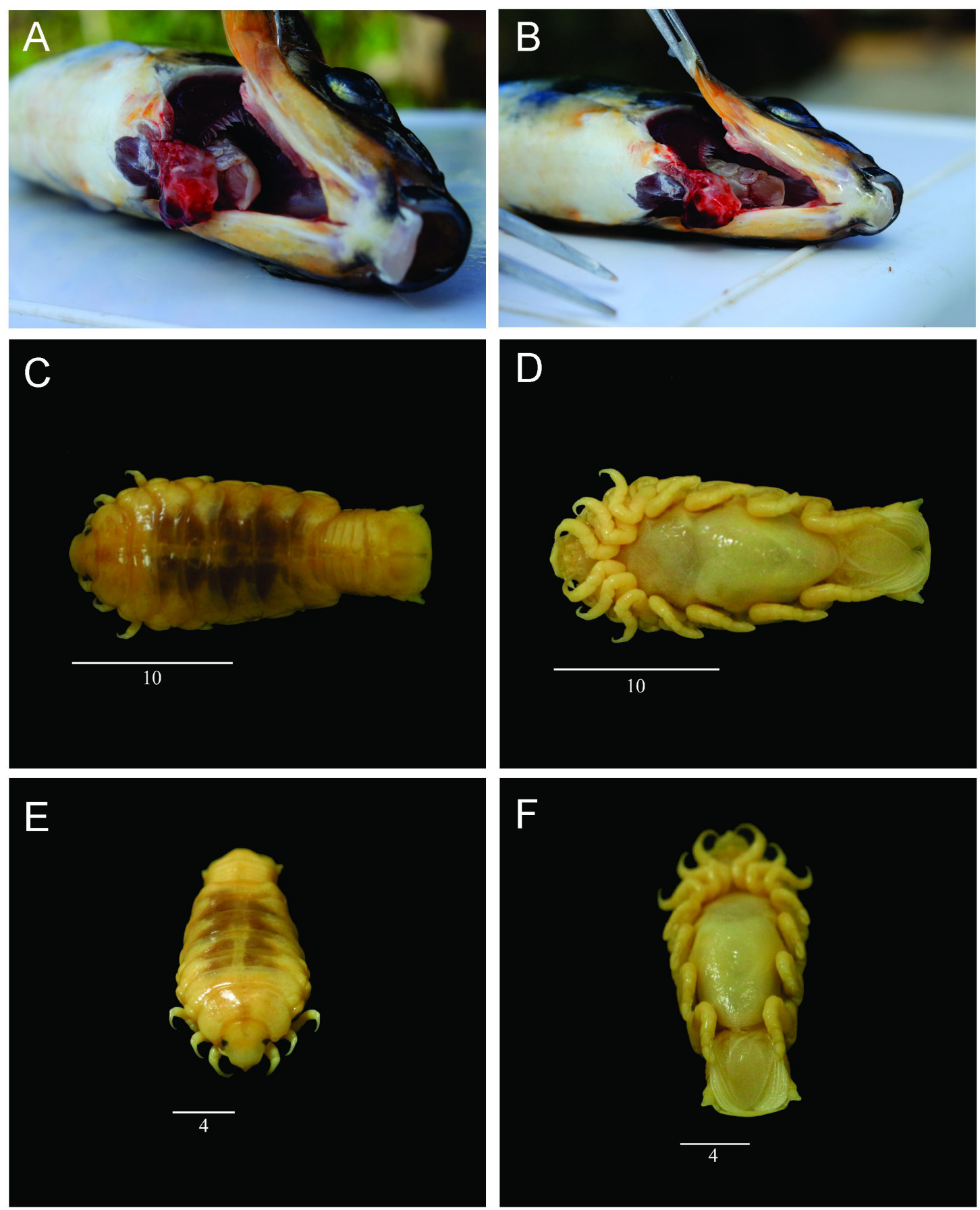

Figure 2. Female of Livoneca guianensis fixed on the tongue of Leporinus fasciatus from the Jari River basin, in eastern Amazon, Brazil (A, B). Views of the Livoneca guianensis dorsal (C) ventral (D), frontal (E) and back (F).

In general, parasitic cymothoids occur with little infestation in gills of host fish because these ectoparasites may cause considerable damage to fish when feeding from mucous and epithelial cells, perforating the fish skin (TavaresDias et al., 2014, 2015). This is related to competition for resource, because possibly the size of the infestation site (i. e. tongue) is a limiting factor for cohabiting two or more specimens of $L$. guianensis or other isopod species of large size. The registration of $L$. guianensis in larger L. fasciatus corroborates the hypothesis that larger fish with a larger available area are more prone to infestation by this isopod species (Arneberg et al., 1998; Poulin, 1999). The low prevalence of this cymothoids may be due to its low fertility rate, infestation, survival, environmental conditions, predation or even host behavior. These parasites infest the ventral part of the opercular cavity or the mouth of their hosts (Thatcher, 2006; Tavares-Dias et al., 2014; Oliveira et al., 2017). In general, the cymothoid species are 
Table 1. Measurement of Livoneca guianensis female collected in Leporinus fasciatus gills from the Jari River, in eastern Amazon (Brazil).

\begin{tabular}{|c|c|}
\hline Measured parameters & Measurements (mm) \\
\hline Total length & 22.0 \\
\hline Total width & 9.0 \\
\hline Head length & 3.4 \\
\hline Head width & 3.3 \\
\hline 1st pereon length & 6.8 \\
\hline 2nd pereon length & 8.5 \\
\hline 3rd pereon length & 9.0 \\
\hline 4th pereon length & 9.0 \\
\hline 5th pereon length & 9.0 \\
\hline 6 th pereon length & 8.3 \\
\hline 7th pereon length & 7.5 \\
\hline 1st dactyl length & 2.5 \\
\hline 2nd dactyl length & 1.5 \\
\hline 3rd dactyl length & 1.0 \\
\hline 4th dactyl length & 1.0 \\
\hline 5th dactyl length & 1.0 \\
\hline 6th dactyl length & 1.5 \\
\hline 7th dactyl length & 1.5 \\
\hline Length $1 \mathrm{st}$ to 5 th pleonite & 6.5 \\
\hline Pleotelson Length & 4.0 \\
\hline Pleotelson width & 5.0 \\
\hline
\end{tabular}

protandrous hermaphrodites, and mainly females are found parasitizing fish, however, males are occasionally found together with females. The presence of $L$. guianensis female without a male partner is a strong indication that the males may have been swept from the oral cavity or swallowed by the host fish (Bakenhaster et al., 2006), but is also possible that the male spontaneously leaves the host, either due to biological necessity or perception of fish stress at the time of host collection. In the present study, L. guianensis was found in the tongue of L. fasciatus, in which small lesions caused by the attachment of the parasite claws were observed. Similar lesions were also attributed to the isopod Braga patagonica Schioedte \& Meinert, 1884 in Colossoma macropomum Cuvier, 1816 tegument (Tavares-Dias et al., 2014).

Species of the genus Livoneca have a wide geographical distribution, with records in Asia, Africa, North America, Central America, South America, and Europe (Bruce, 1990). However, the taxonomic status of most Livoneca species, including L. guianensis, is considered uncertain (Bruce, 1990). Therefore, new taxonomic revisions of these species are necessary, of which can change the biogeographical status currently established for these isopods. After description of L. guianensis collected in L. fasciatus and P. clarias in Guyana (Van Name, 1925), this parasite was found in Brazil in the oral cavity of Leporinus friderici Bloch, 1794 in the Jari River, a tributary of the Amazon River basin in Northern Brazil (Oliveira et al., 2017). Therefore, L. guianensis has a distribution exclusive to South America and may be widely distributed in this Neotropical region. In conclusion, this study contributed the first report of the occurrence of $L$. guianensis in L. fasciatus in Brazil, thus increasing our knowledge about the geographic distribution of this parasite. Furthermore, the present study contributed morphometric data, which are scarce for this cymothoid.

\section{Acknowledgements}

We would like to thank Mr. João Pena de Oliveira for his assistance in collecting fish, to the National Council for Scientific and Technological Development/CNPq (Conselho Nacional de Desenvolvimento Científico e Tecnológico) for the research grant provided to Tavares-Dias, M (Grant 303013/2015-0), to the Post-graduate Program of studies in Tropical Biodiversity (PPGBio - Programa de Pós-graduação em Biodiversidade Tropical) and Coordination for 
the Improvement of Higher Education Personnel (CAPES - Coordenação de Aperfeiçoamento de Pessoal de Nível Superior) for granting a doctoral fellowship to Oliveira, MSB.

\section{References}

Arneberg P, Skorping A, Read AF. Parasite abundance, body size, life histories, and the energetic equivalence rule. Am Nat 1998; 151(6): 497-513. http://dx.doi.org/10.1086/286136. PMid:18811372.

Bakenhaster MD, McBride RS, Price WW. Life history of Glossobius hemiramphi (Isopoda: Cymothoidae): development, reproduction, and symbiosis with its host Hemiramphus brasiliensis (Pisces: Hemiramphidae). J Crustac Biol 2006; 26(3): 283-294. http://dx.doi. org/10.1651/C-2573.1.

Boyko CB, Bruce NL, Hadfield KA, Merrin KL, Ota Y, Poore GCB, et al. Cymothoidae Leach, 1818 [online]. World Register of Marine Species; 2008 [cited 2020 Jul 3]. Available from: http://marinespecies.org/aphia.php?p=taxdetails\&id=118274

Bruce N. The genera Catoessa, Elthusa, Enispa, Ichthyoxenus, Idusa, Livoneca and Norileca n. gen. (Isopoda, Cymothoidae), crustacean parasites of marine fishes, with descriptions of Eastern Australian species. Rec Aust Mus 1990; 42(3): 247-300. http://dx.doi.org /10.3853/j.0067-1975.42.1990.118.

Oliveira MSB, Corrêa LL, Ferreira DO, Neves LR, Tavares-Dias M. Records of new localities and hosts for crustacean parasites in fish from the eastern Amazon in northern Brazil. J Parasit Dis 2017; 41(2): 565-570. http://dx.doi.org/10.1007/s12639-016-08528. PMid:28615880.

Poulin R. Body size vs abundance among parasite species: positive relationships? Ecography 1999; 22(3): 246-250. http://dx.doi. org/10.1111/j.1600-0587.1999.tb00499.x.

Queiroz LJ, Torrente-Vilara G, Ohara WM, Pires THS, Zuano J, Doria CR. Peixes do Rio Madeira. 1. ed. São Paulo: Dialeto Latin American Documentary; 2013. (vol. 1).

Smit NJ, Bruce NL, Hadfield KA. Global diversity of fish parasitic isopod crustaceans of the family Cymothoidae. Int J Parasitol Parasites Wildl 2014; 3(2): 188-197. http://dx.doi.org/10.1016/j.ijppaw.2014.03.004. PMid:25180163.

Tavares-Dias M, Araújo CS, Barros MS, Viana GM. New hosts and distribution records of Braga patagonica, a parasite Cymothoidae of fishes from the Amazon. Braz J Aquat Sci Tech 2014; 18(1): 91-97. http://dx.doi.org/10.14210/bjast.v18n1.p91-97.

Tavares-Dias M, Dias-Júnior MBF, Florentino AC, Silva ALM, Cunha AC. Distribution pattern of crustacean ectoparasites of freshwater fish from Brazil. Rev Bras Parasitol Vet 2015; 24(2): 136-147. http://dx.doi.org/10.1590/S1984-29612015036. PMid:26154954.

Thatcher VE. Amazon fish parasites. 2nd ed. Moscow: Pensoft Publishers Sofia; 2006. (vol. 1).

Van Name BWG. The isopods of Kartabo, Bartica district, British Guiana. Zoologica 1925; 6(5): 461-503. 